\title{
A New Method for Assessing Deep Catastrophic Landslide Susceptibility
}

\author{
Taro UCHIDA ${ }^{1}$, Osamu YOKOYAMA ${ }^{2}$, Ryuji SUZUKI ${ }^{3}$, \\ Keiji TAMURA ${ }^{4}$, Tadanori ISHIZUKA ${ }^{2}$, \\ ${ }^{1}$ Erosion and Sediment Control Division, National Institute for Land and Infrastructure Management (Tsukuba, Ibaraki, 3050804, \\ Japan) \\ Email: uchida-t92rv@nilim.go.jp \\ 2 Volcano and Debris Flow Research Team, Public Works Research Institute (Tsukuba, Ibaraki, 3058516, Japan) \\ 3 Disaster Prevention and Mitigation Engineering Office (Tokyo, 1740065, Japan) \\ ${ }^{4}$ Unzen Restoration Work Office, Kyushu Regional Beaurou, Ministry of Land, Infrastructure, Transport and Tourism (Shimabara, \\ Nagasaki, 8560866, Japan)
}

\begin{abstract}
In steep mountainous regions, deep catastrophic landslides that involve weathered bedrock as well as soils can cause serious damage. However, there is currently no widely used method for estimating spatial patterns of susceptibility to deep catastrophic landslides. We propose a new method to estimate landslide susceptibilities for many small catchments $\left(\sim 1 \mathrm{~km}^{2}\right)$ over relatively large areas (hundreds of square kilometers). Our method identifies catchments prone to deep catastrophic landslides according to three criteria: (1) catchments with ancient deep catastrophic landslide scars, (2) catchments with faults and landforms caused by long-lasting mass movements, and (3) catchments with many steep slopes that have large upslope contributing areas. We demonstrated the applicability of this method using data from Mount Wanitsuka, Miyazaki Prefecture, Japan, where deep catastrophic landslides occurred during a typhoon in 2005.
\end{abstract}

Key words: Deep catastrophic landslide, susceptibility assessment, landform, aerial photograph, topography

\section{INTRODUCTION}

In steep mountainous regions, landslides may include not only soils, but also underlying weathered bedrock. The velocities and volumes of these landslides are often very large. We refer to these landslides as "deep catastrophic landslides" (Fig. 1), but have excluded from this category slow failures of a more chronic nature such as deepseated chronic landslides and deep-seated gravitational creep and rock flows.

Deep catastrophic landslides may cause serious damage. For example, a deep catastrophic landslide killed more than 400 people in Shaolin Village, Taiwan, in 2009 [Shieh et al., 2009], and more than 1100 people were killed on Leyte Island, Philippines, in 2006 [Evans et al., 2007]. Deep catastrophic landslides may also form landslide dams and have serious impacts on human lives and infrastructure [e.g., Costa and Schuster, 1988; Uchida et al., 2009]. Reducing these hazards requires the development of objective methods to assess and map potential sources of deep catastrophic landslides. Uchida et al. [2007] showed that the frequency of deep catastrophic landslides is strongly affected by bedrock geology and rock uplift rate. Considering this, we roughly classified Japan into four categories of past deep catastrophic landslides frequency [Uchida et al., 2007]. However, there is no widely used method for estimating spatial patterns of deep catastrophic landslide susceptibility on the scale of individual

(a) Shallow landslide

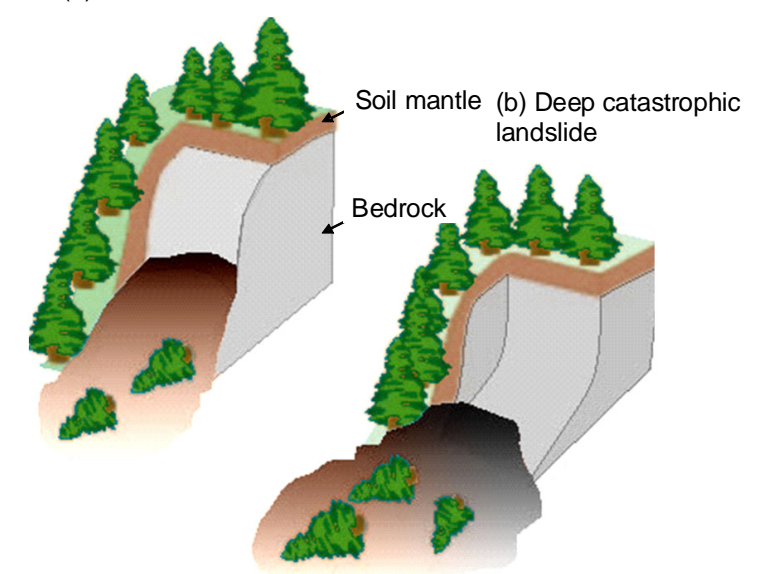

Fig. 1 Conceptual diagram of a shallow landslide (a) and a deep catastrophic landslide (b) 
catchments or hillslopes [Montgomery, 2001].

Several recent studies have addressed the deep catastrophic landslide susceptibility of catchments or hillslopes. For example, Jitousono et al. [2008] presented data about hydrological conditions at slopes where deep catastrophic landslides have occurred and proposed a method for estimating susceptibility using water chemistry of streams and springs. Several technologies have been used to analyze long-lasting mass movements, which often progress to deep catastrophic sliding [e.g., Chigira and Kiho, 1994; Crosta and Agliardi, 2003; Chigira, 2009], including airborne laser altimetry [e.g., Kasai et al., 2009; Uchida et al., 2010], differential interferometric synthetic aperture radar [e.g., Roering et al., 2009], and helicopter-borne electromagnetic surveys [Suzuki et al., 2009]. However, these methods are not feasible for assessment of deep catastrophic landslide susceptibility for areas of several hundred square kilometers because of their budgetary and labor demands.

Since the 1960s, field investigations of landforms and geologic structures on slopes where deep catastrophic landslides have occurred have yielded much information [e.g., Machida, 1967; Hatano, 1974]. However, this information has not been successfully used to assess spatial patterns of deep catastrophic landslide susceptibility. Therefore, we reviewed previous studies of landforms and geologic structures on these slopes [e.g., Suzuki et al., 2007; Yokoyama et al., 2011]. We also conducted new analysis using data for recent deep catastrophic landslides [e.g., Yokoyama et al., 2011]. On the basis of the review and new data analysis, we propose a new method for estimating spatial patterns of deep catastrophic landslide susceptibility for many small catchments over relatively large areas. The method was published as a manual for assessing spatial patterns of potential deep catastrophic landslide sources [Tamura et al., 2008].

Here, we briefly introduce our previous studies regarding the role of landforms and geologic structures in deep catastrophic landslide occurrence in section 2. We then introduce our proposed method for estimating spatial patterns of deep catastrophic landslide susceptibility in section 3 . Finally, we tested this method in a $130-\mathrm{km}^{2}$ study area around Mount Wanitsuka, Miyazaki Prefecture, Japan using new dataset, as described in sections 4 and 5 .

\section{CHARACTERISTICS OF DEEP CATASTROPHIC LANDSLIDES}

Several lines of evidence suggest possible indices for efficient determination of a site's susceptibility to deep catastrophic landslides. These include historical, geomorphic, geologic, and topographic data.

\subsection{Ancient deep catastrophic landslide}

Shimokawa and Iwamatsu [1986], Takaya and Suzuki [2007], and Suzuki et al. [2007] showed that scars of ancient deep catastrophic landslides are often found near new deep catastrophic landslides. Jitousono et al. [2008] also argued that new catastrophic landslides are likely to occur where ancient deep catastrophic landslide scars exist. Yokoyama et al. [2011] found that deep catastrophic landslides have a significantly higher probability of

Table 1 Characteristics of landforms related to deep catastrophic landslides

\begin{tabular}{|c|c|}
\hline Landforms & Characteristics \\
\hline Old deep catastrophic landslide scar & Areas bounded by well-defined arcuate head scarps \\
\hline \multirow[t]{3}{*}{ Rock creep slope } & Poorly developed hollows or valleys \\
\hline & Sides often bounded by small hollows \\
\hline & Concave and convex knicklines \\
\hline \multirow[t]{3}{*}{ Ancient deep-seated chronic landslide } & Areas bounded by well-defined arcuate head scarp \\
\hline & Several interior scarps \\
\hline & Bulging toe \\
\hline \multirow[t]{2}{*}{ Downhill-facing scarp } & Scarps run generally above landslide headscarp \\
\hline & Arcuate shape \\
\hline \multirow[t]{3}{*}{ Linear depression } & Bounded by uphill- and downhill-facing scarps \\
\hline & Include double-crested ridge \\
\hline & Commonly running along ridge lines \\
\hline \multirow[t]{3}{*}{ Gentle ridge top } & Relatively flat-lying part at ridge tops surrounded by convex \\
\hline & knicklines \\
\hline & Low relief \\
\hline
\end{tabular}




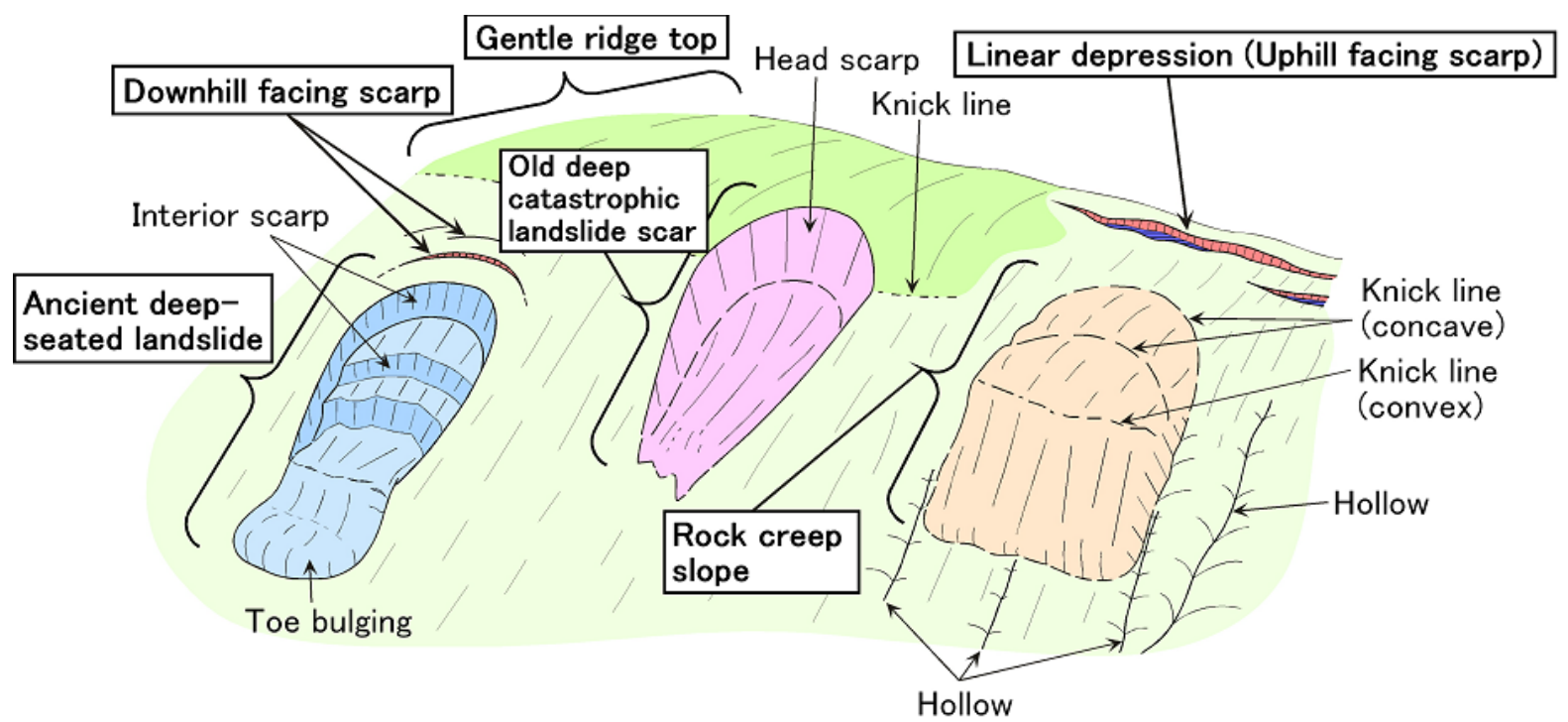

Fig. 2 Conceptual diagram of landforms related to landsliding (see Table 1)

occurrence near ancient deep catastrophic landslide scars than far from them. These studies suggest that ancient deep catastrophic landslide scars may be an index of susceptibility to deep catastrophic landslides.

\subsection{Landforms from long-lasting mass movements}

Long-lasting, small-scale mass movements called gravitational mass rock creeps sometimes lead to deep catastrophic sliding. The terms deepseated gravitational creep, sackung (sagging), and rock flow have been used to denote similar phenomena [e.g., Brückl and Parotidis, 2005]. Indeed, evidence of gravitational mass rock creep is often observed at the scars of deep catastrophic landslides [e.g., Iwamatsu and Shimokawa, 1986; Wang et al., 2003]. Slopes affected by gravitational mass rock creep (hereafter, "rock creep slopes") have been mapped from aerial photographs, and their positional relationship with deep catastrophic landslides has been analyzed [e.g., Suzuki et al., 2007; Yokoyama et al., 2011]. These studies showed that rock creep slopes are common in areas near deep catastrophic landslides, suggesting that rock creep slopes might serve as an index for assessing deep catastrophic landslide susceptibility.

In addition, Terado [1986] reported ancient deep-seated chronic landslides in areas near recent deep catastrophic landslides. Both gravitational mass rock creep and deep-seated chronic landslides have been shown to be associated with doublecrested ridges, linear depressions, uphill-facing scarps (counterscarps), small downhill-facing scarps, and cracks and trenches [e.g., Chigira, 1992; Agliardi et al., 2009; Nishii and Matsuoka,
2010] (Fig. 2). These landforms have also been shown to be common around deep catastrophic landslides [Hatano, 1974; Mokudai and Chigira, 2004; Crosta et al., 2006; Chigira, 2009; Yokoyama et al., 2011]. These studies suggest that landforms associated with long-lasting mass movements may be useful for assessment of deep catastrophic landslide susceptibility.

\subsection{Geologic structures}

Geologic structures are also thought to contribute to deep catastrophic landslides because geologic structures often control long-lasting mass movements [e.g., Agliardi et al., 2009]. Previous studies have reported the presence of faults in areas close to deep catastrophic landslides [e.g., Nakagawa and Okunishi, 1977; Teramoto et al., 1987; Takaya and Suzuki, 2006; Chigira, 2009]. These findings suggest that the spatial distribution of faults can provide useful information about deep catastrophic landslide susceptibility.

\subsection{Topography}

Generally, mass movements on hillslopes are strongly controlled by local slope angle [e.g., Hatano, 1974; Montgomery, 2001]. Deep catastrophic landslides are no exception. Korup et al. [2007] and Korup and Schlunegger [2007] have shown that local relief controls deep catastrophic landslides.

Moreover, an area's susceptibility to shallow landslides is known to be controlled not only by local slope angle, but also by the upslope contributing area through its effect on increasing soil pore water pressure [e.g., Hatano, 1974; Montgomery and Dietrich, 1994]. For deep 


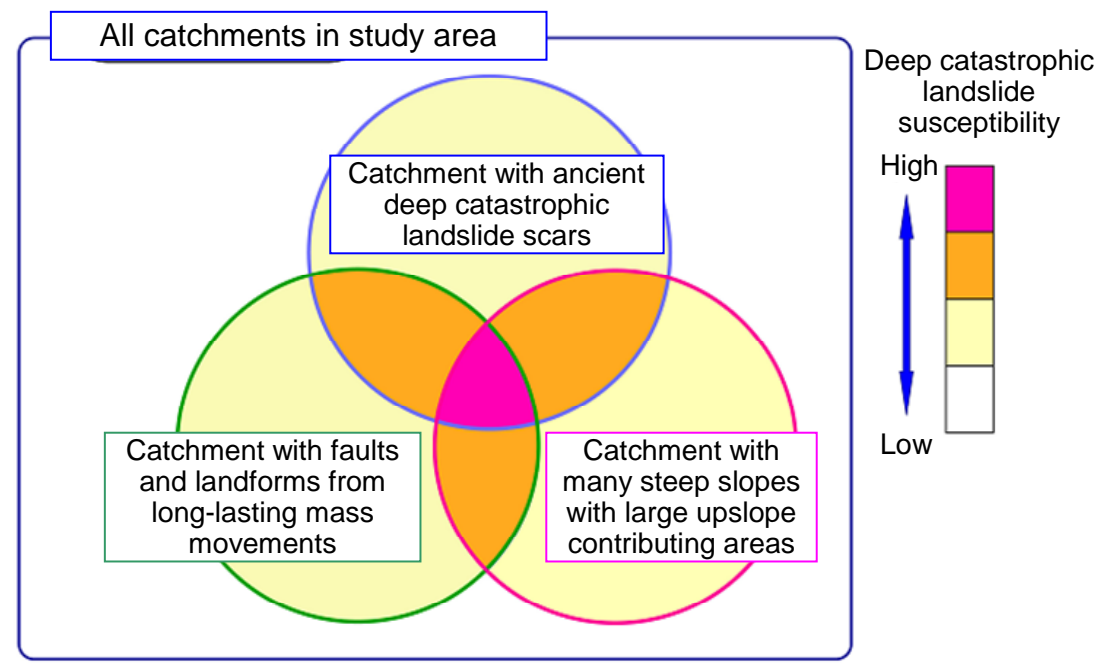

Fig. 3 Schematic diagram of proposed method for assessing deep catastrophic landslide susceptibility

catastrophic landslides, the role of the upslope contributing area is not fully understood because groundwater flow cannot be fully described by surface topography [e.g., Uchida et al., 2008; Jitousono et al., 2008]. However, it is plausible that the upslope contributing area of steep slopes with large local relief should be large. Many researchers have noted that upper slopes above the head of deep catastrophic landslides are often gentle compared with the slopes where deep catastrophic landslides occurred [e.g., Machida, 1967; Terado, 1986; Teramoto et al., 1987; Chigira, 2009; Mokudai and Chigira, 2004]. This suggests that deep catastrophic landslides tend to initiate along convex slope breaks (Fig. 2). If the edges of relatively gentle ridge tops are more susceptible to deep catastrophic landslides, then the hypothesis that steep slopes with large upslope contributing areas have greater deep catastrophic landslide susceptibility is supported.

\section{ASSESSING POTENTIAL DEEP CATASTROPHIC LANDSLIDE SOURCES}

\subsection{Outline of the method}

We developed a method for assessing the susceptibility of small catchments $\left(\sim 1 \mathrm{~km}^{2}\right)$ to deep catastrophic landslides over relatively large areas (hundreds of square kilometers). Considering the review in section 2, we proposed three criteria for determining a susceptible catchment (Fig. 3):

1. Presence of ancient deep catastrophic landslide scars.

2. Presence of faults or landforms caused by longlasting mass movements.

3. Presence of many steep slopes with large upslope contributing areas.

Moreover, we hypothesized that the susceptibility of a given catchment increases with the number of these criteria that are satisfied. Because deep catastrophic landslide frequency was not high, it was difficult to conduct statistical analysis to weight these criteria. Therefore, we simply used the number of these criteria that were satisfied as the susceptibility.

To determine detailed criteria about faults, landforms, and topography, we conducted preliminary analyses. Because landslide processes are strongly affected by bedrock geology and climate, we limited our preliminary analyses to a study area with homogeneous bedrock geology and climatic conditions (Fig. 4). Many previous empirical models for assessing shallow landslides have been developed using regression analysis between parameters, such as slope angle and slope curvature, and landslide susceptibility [e.g., Guzzetti et al., 2005]. However, because the numbers of historical deep catastrophic landslides were not high, regression analyses would not have been suitable. To clarify the roles of landforms and topography, we used two indices (normalized hit ratio and cover ratio) proposed by Yokoyama et al. [2011] (see 3.3). Yokoyama et al. [2011] successfully quantified relationships between deep catastrophic landslides, landforms, and geological structures.

Using the detailed criteria determined by the preliminary analyses, we assessed the susceptibility to deep catastrophic landslides for each small catchment in the study area (Fig. 4).

\subsection{Mapping deep catastrophic landslides, landforms, and geologic structures}

We created an inventory map of deep catastrophic landslides by stereoscopic examination of aerial photographs. We also included all deep catastrophic landslides shown on the geologic map. 


\section{Determination of study area}

-Area under homogenous bedrock geology and climate condition was determined as the study area.

-Study area was divided into small catchments (area is around $1 \mathrm{~km}^{2}$ ), which evaluated landslide susceptibility

\section{Data preparation and mapping \\ -Aerial photograph, geological maps, DEM were prepared \\ -Based on the interpretation of aerial photographs, ancient deep catastrophic landslide scars and landforms were mapped. \\ -Slope angle and upslope contributing area were computed using DEM.}

\section{Preliminary analysis using historical data}

-To determine detailed criteria, the relationship between old deep catastrophic landslide, landform, geological structures and topography were examined.

\section{Assessing deep catastrophic landslide susceptibility}

-Based on the determined criteria, the susceptibility of future deep catastrophic land slide in each catchment were assessed.

Fig. 4 Flowchart of the proposed method for assessing deep catastrophic landslide susceptibility

The mapped landslides included the entire landslide scar, excluding the runout zone, limited to the locations where the landslides initiated.

We also mapped four landform types related to long-lasting mass movements by interpretation of aerial photographs: rock creep slopes, ancient deepseated chronic landslides, downhill-facing scarps, and linear depressions (Fig. 2). In addition, we mapped gentle ridge tops. We defined the characteristics of these landforms (Fig. 2 and Table 1) on the basis of previous studies [e.g., Hatano, 1974; Chigira, 1992; Chigira and Kiho, 1994; McKean and Roering, 2004; Roering et al., 2005; Nishii and Matsuoka, 2010] for our interpretation of aerial photographs. Finally, we used geologic maps to compile active and inactive faults that might control deep catastrophic landslides.

\subsection{Preliminary analyses for choosing susceptibility criteria}

\subsubsection{Landforms and geologic structures}

Our preliminary analysis focused on the relationships between landforms, geologic structures, and previous deep catastrophic landslides. First, we divided the study area into catchments with areas of approximately $1 \mathrm{~km}^{2}$. If the polygon of a given catchment overlapped an ancient deep catastrophic landslide polygon, we defined the catchment as an "old landslide catchment."

To examine the relationships between landforms, geologic structures, and old landslides, we calculated the normalized hit ratio $P_{i}$ and cover ratio $C_{i}$ for each landform or geologic structure using the equations

$$
\begin{gathered}
P_{i}=\frac{N_{L, i} / N_{i}}{N_{L} / N} \\
C_{i}=\frac{N_{L, i}}{N_{L}}
\end{gathered}
$$

where $N_{L, i}$ is the number of old landslide catchments with landform or geologic structure $i, N_{i}$ is the number of catchments with landform or geologic structure $i, N_{L}$ is the number of all old landslide catchments in the study area, and $N$ is the number of all catchments in the study area.

As the first step, two or three landforms or geologic structures with high $P$ and $C$ were chosen as candidates that might be strongly related to deep catastrophic landslides. We then combined these candidates into a single index and calculated $P$ and $C$ values for the index to assess its relationship to deep catastrophic landslide occurrence. The method for combination was as follows: for example, given "rock creep slope" and "active fault" as candidates, we calculated the $P$ and $C$ values for catchments with (1) "rock creep slope" AND "active fault" and (2) "rock creep slope" AND/OR "active fault." Finally, we assessed catchments with geological structures and/or landforms that have high $P$ and $C$ values as high-susceptibility catchments for deep catastrophic landslides in terms of their landform and geologic structure.

\subsubsection{Topography}

In our topographic analysis, we examined the relationship between three quantities: old landslide ratio, local slope angle, and upslope contributing area. The old landslide ratio was calculated as follows. We divided grid cells into 72 topographic categories in terms of local slope angle and upslope contributing area (Table 2). If the center of a given cell was inside an ancient deep catastrophic landslide polygon, we defined it as a "landslide cell." We calculated the old landslide ratio as the ratio of landslide cells to the total number of cells in 
each topographic category. We calculated the local slope angle and upslope contributing area using the D8 single-flow-direction procedure [O'Callaghan and Mark, 1984]. If the old landslide ratio of a topographic category was more than twice the mean landslide ratio in the study area (the ratio of all landslide cells to all cells in the study area), cells in that category were considered "highly susceptible cells."

Next, to examine the relationship between highly susceptible cells in a catchment and ancient deep catastrophic landslides, the normalized hit ratio $P(n)$ and cover ratio $C(n)$ at different threshold numbers $n$ of highly susceptible cells were calculated as

$$
\begin{aligned}
& P(n)=\frac{N_{L}(n) / N(n)}{N_{L} / N} \\
& C(n)=\frac{N_{L}(n)}{N_{L}}
\end{aligned}
$$

where $N(n)$ is the number of catchments exceeding $n$ highly susceptible cells and $N_{L}(n)$ is the number of old landslide catchments exceeding $n$ highly susceptible cells. Finally, we assessed catchments exceeding the threshold number of highsusceptibility cells as high-susceptibility catchments for deep catastrophic landslides in terms of topography.

\section{APPLICABILITY TEST OF PROPOSED METHOD}

\subsection{Study site}

We applied our proposed method to a study area surrounding Mount Wanitsuka in Miyazaki Prefecture, western Japan (Fig. 5). The region is humid and temperate: the mean annual precipitation in this region is around $2600 \mathrm{~mm}$, and the mean temperature is around $18^{\circ} \mathrm{C}$. The studied area covered approximately $130 \mathrm{~km}^{2}$, with altitudes ranging from 150 to $1118 \mathrm{~m}$. The site is deeply incised and dominated by hillslopes, with small riparian area. Streams are very steep with longitudinal gradients ranging from $5^{\circ}$ to $20^{\circ}$. Slope angles range from $15^{\circ}$ to $40^{\circ}$, and slope lengths range from 100 to $1500 \mathrm{~m}$. The area is underlain by sedimentary rocks (sandstone and mudstone) of the Cretaceous Shimanto Group. The area is covered by forest.

Twelve deep catastrophic landslides occurred in the study area during 5-9 September 2005, and these landslides triggered many debris flows [Taniguchi, 2008]. Total rainfall of $1013 \mathrm{~mm}$ and maximum rainfall intensity of $43 \mathrm{~mm} / \mathrm{h}$ were measured at the summit of Mount Wanitsuka during the triggering event.

\subsection{Data and preparation}

The study area was divided into 95 catchments with areas ranging from 0.3 to $5.8 \mathrm{~km}^{2}$ (Fig. 5). Thus, the value of $N$ in equations 1 and 3 was 95 .

We mapped the deep catastrophic landslides triggered in September 2005 ("new landslides") using 1:8000 aerial photographs taken just after the heavy rainfall. In two catchments, multiple new deep landslides occurred. Six catchments were found to have one new landslide. We also mapped ancient deep catastrophic landslide scars ("old landslides") using 1:16,000 aerial photographs taken in 2003, and included deep catastrophic landslides mapped on the Engineering Geological Map of Kyushu Region, as old landslides. In addition, we mapped landforms including rock creep slopes, ancient deep-seated chronic landslides, downhill-facing scarps, linear depressions, and gentle ridge tops from the 2003 aerial photographs using the definitions in Table 1.

The distribution of active faults was based on the Digital Active Fault Map of Japan. Inactive faults were taken from mapped faults shown on the Seamless Digital Geological Map of Japan (1:200,000) published by Geological Survey of Japan that did not match those on the Digital Active Fault Map. We created polygon data for old landslides, new landslides, rock creep slopes, ancient deep-seated chronic landslides, and gentle ridge tops and used line data for downhill-facing scarps, linear depressions, and active and inactive faults. We used a 50-m digital elevation model (DEM) supplied by the Geographical Survey Institute of Japan to calculate local slope angles and upslope contributing areas.

\section{RESULTS AND DISCUSSION}

\subsection{Relationship between old landslides and landforms or geologic structures}

Normalized hit ratios $P$ of catchments with active faults, rock creep slopes, and downhill-facing scarps were $>1.8$. $P$-values of catchments with inactive faults, ancient deep-seated chronic landslides, and gentle ridge tops were approximately 1.0 , meaning that the possibility of old landslides existing in these catchments was almost the same as the average possibility in the whole study area (Fig. 6). We did not find any linear depression in the study area. 


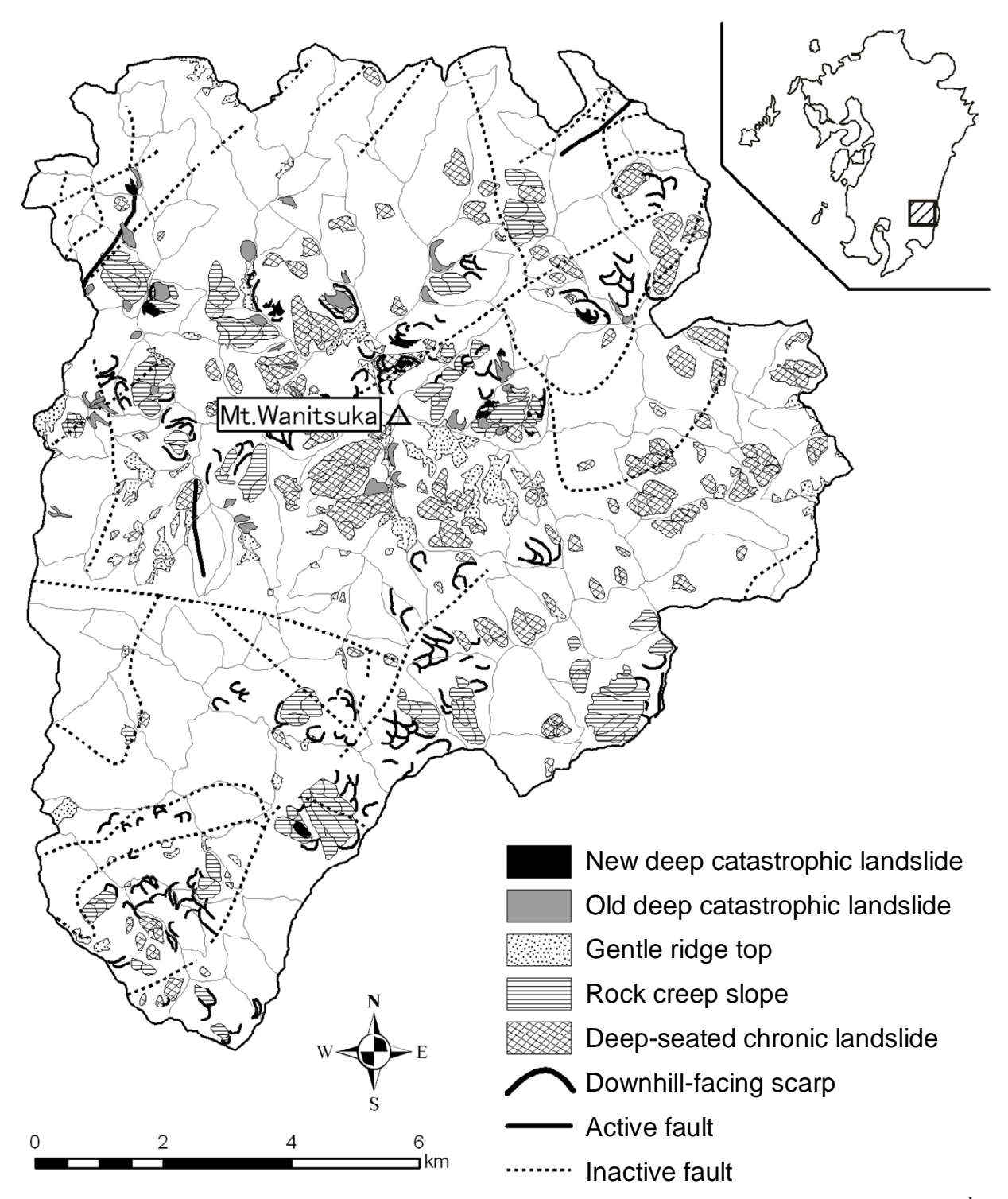

Fig. 5 Map of study area showing outlines of 95 catchments and landslide-related features. The inset map shows the study area location on Kyushu Island, western Japan

Cover ratios $C$ of catchments with inactive faults and rock creep slopes were $>0.5 ; C$ values of catchments with downhill-facing scarps, ancient deep-seated chronic landslides, and gentle ridge tops were approximately 0.4 ; and $C$ values of catchments with active faults were approximately 0.13 (Fig. 7). That is, catchments with rock creep slopes and downhill-facing scarps had high $P$ and $C$ values. We chose rock creep slopes and downhillfacing scarps as landforms related to deep catastrophic landslide occurrence.

Next, we calculated $P$ and $C$ for catchments with (1) rock creep slopes AND downhill-facing scarps and (2) rock creep slopes AND/OR downhill-facing scarps (Figs. 6 and 7). Our results indicated that catchments with rock creep slopes, downhill-facing scarps, or both have the highest values of $P(2.1)$ and $C(0.61)$. Subsequently, we defined catchments with rock creep slopes and/or downhill-facing scarps as highly susceptible to deep catastrophic landslides in terms of landforms and geologic structures.

\subsection{Relationship between topography and old landslides}

Table 2 shows the relationship of the landslide ratio to different combinations of local slope angle and upslope contributing area. We confirmed that the landslide ratio increased with both local slope angle and upslope contributing area. Landslide 


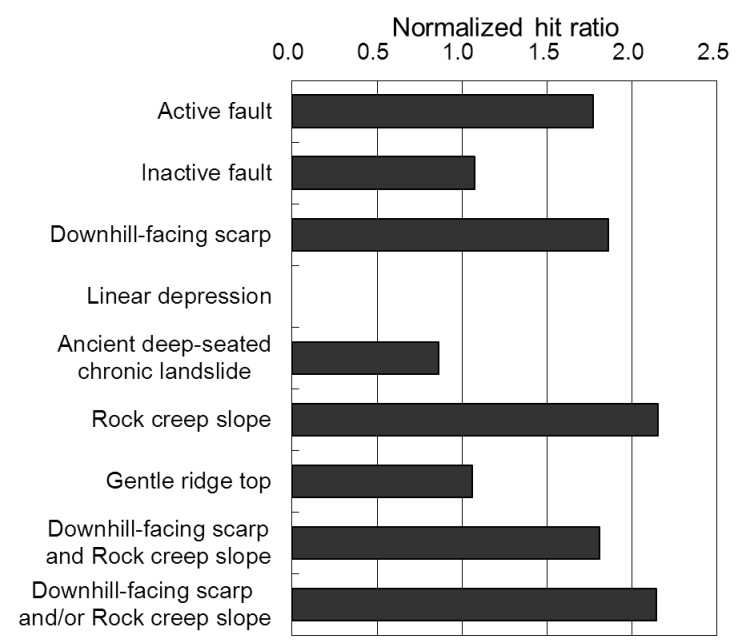

Fig. 6 Normalized hit ratios of features related to deep catastrophic landslide susceptibility

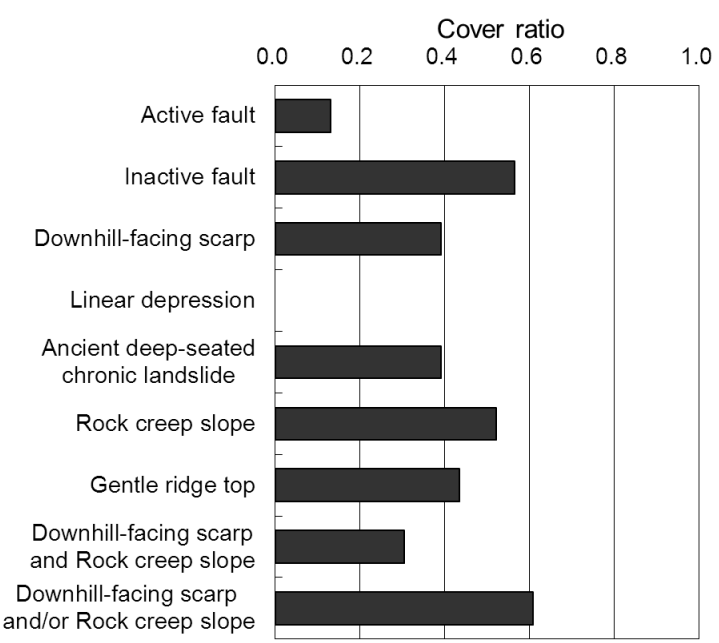

Fig. 7 Cover ratios of features related to deep catastrophic landslide susceptibility

Table 2 Landslide ratios resulting from combinations of local slope angle and upslope contributing area. Shaded categories represent less than $1 \%$ of all grid cells in the study area. The red line encloses highly susceptible topographic categories

\begin{tabular}{|c|c|c|c|c|c|c|c|c|c|}
\hline \multirow{3}{*}{$\begin{array}{l}\text { Local slope } \\
\text { angle (deg.) }\end{array}$} & \multicolumn{9}{|c|}{ Upslope contributing area $\left(\log \left(\mathrm{m}^{2}\right)\right)$} \\
\hline & 24 & 27 & $3.9 \sim$ & $4.1 \sim$ & $4.4 \sim$ & $4.7 \sim$ & $5.1 \sim$ & $5.4 \sim$ & $5.7 \sim$ \\
\hline & 3.4 & 3.1 & 4.0 & 4.4 & 4.7 & 5.1 & 5.4 & 5.7 & \\
\hline$\sim 10$ & 0.0 & 0.0 & 0.0 & 0.0 & 0.0 & 0.0 & 0.0 & 0.0 & 0.0 \\
\hline $10 \sim 15$ & & 0.0 & 0.0 & 0.5 & 0.6 & 0.0 & 0.0 & 0.0 & 0.0 \\
\hline $15 \sim 20$ & & 0.8 & 0.6 & 1.3 & 1.7 & 0.0 & 0.0 & 1.7 & 0.0 \\
\hline $20 \sim 25$ & & 0.4 & 0.9 & 1.8 & 1.6 & 3.4 & 3.6 & 0.0 & 0.0 \\
\hline 25 & & 1.3 & 1.6 & 1.1 & 3.2 & 1.1 & 4.3 & 0.0 & 0.0 \\
\hline $30 \sim 35$ & 2.6 & 1.3 & 4.1 & 6.8 & 3.4 & 0.0 & 0.0 & 0.0 & 0.0 \\
\hline $35 \sim 40$ & 0.0 & 3.0 & 2.5 & 3.5 & 0.0 & 0.0 & 0.0 & 0.0 & 0.0 \\
\hline $40 \sim$ & 0.0 & 0.0 & 0.0 & 0.0 & 0.0 & 0.0 & 0.0 & 0.0 & 0.0 \\
\hline
\end{tabular}

ratios of categories outlined in red in Table 2 were more than twice the mean value for the study area. We chose cells matching the categories outlined in red in Table 2 as highly susceptible cells.

Figure 8 shows $P$ and $C$ values at different values of susceptibility threshold $n$ in equations 3 and 4. Cover ratio decreased with increasing $n$, whereas the normalized hit ratio was the highest at $n=200$. We subsequently defined catchments with $>200$ highly susceptible grid cells meeting the conditions shown in Table 2 as highly susceptible to deep catastrophic landslides in terms of topography.

\subsection{Assessing deep catastrophic landslide susceptibility}

On the basis of the results of the preliminary analyses described in sections 5.1 and 5.2, we used the following three criteria to assess deep catastrophic landslide susceptibility for each catchment:

1. Catchments with ancient deep catastrophic landslide scars

2. Catchments with rock creep slopes and/or downhill-facing scarps

3. Catchments with $>200$ highly susceptible grid cells (Table 2)

Of our 95 catchments, 50 did not satisfy any of these criteria (Fig. 9). We confirmed that no deep catastrophic landslides occurred in these catchments during the storms of September 2005. In the remaining catchments, 25,16 , and 4 satisfied 1,2 , and 3 criteria, respectively. The ratio of catchments with new deep catastrophic landslides to all catchments increased as the number of satisfied criteria increased (Fig. 9). Figure 10 shows the numbers of catchments with new landslides and the number of catchments satisfying the given criteria. We confirmed that our three proposed criteria were effective for assessing landslide susceptibility. These results demonstrate that our proposed method can be used to assess the relative susceptibility of $1-\mathrm{km}^{2}$ catchments to deep catastrophic landslides over relatively large areas 
$\left(130 \mathrm{~km}^{2}\right)$.

\section{CONCLUSIONS}

Our review of previous studies suggests that 1. Susceptibility to deep catastrophic landslides may be high where many deep catastrophic landslides occurred in the past.

2. The spatial distribution of landforms related to long-lasting mass movements, such as rock creep slopes, ancient deep-seated chronic landslides, linear depressions, and downhill-facing scarps, may provide an index for deep catastrophic landslide susceptibility.

3. The spatial distribution of geologic structures that control long-lasting mass movements, such as active faults, may provide an index for deep catastrophic landslide susceptibility.

4. Deep catastrophic landslide susceptibility may be high on steep slopes with large upslope contributing

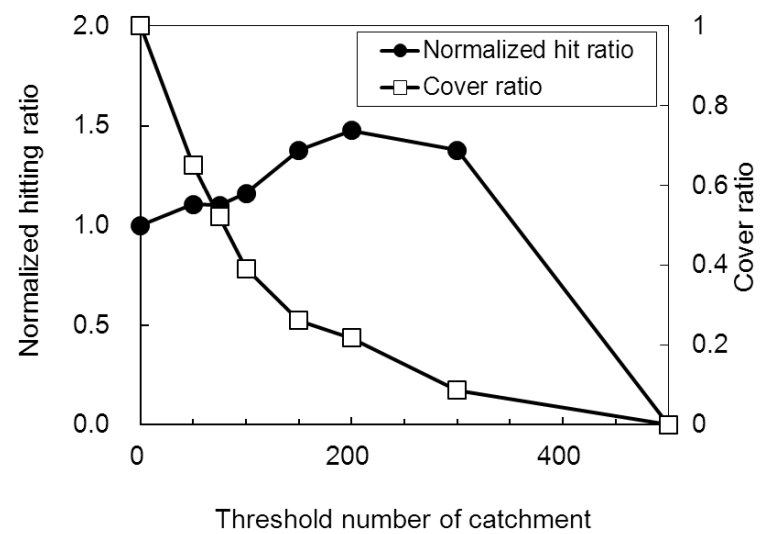

Fig. 8 Plot showing variation of normalized hit ratio and cover ratio with threshold number of high-susceptibility grid cells areas.

5. Deep catastrophic landslide susceptibility may be high at the edge of gentle ridge tops.

From these considerations, we proposed a new method for estimating spatial patterns of deep catastrophic landslide susceptibility for many small catchments over large areas. Our method identifies catchments prone to deep catastrophic landslides according to three criteria: (1) catchments with ancient deep catastrophic landslide scars, (2) catchments with faults and landforms caused by long-lasting mass movements, and (3) catchments

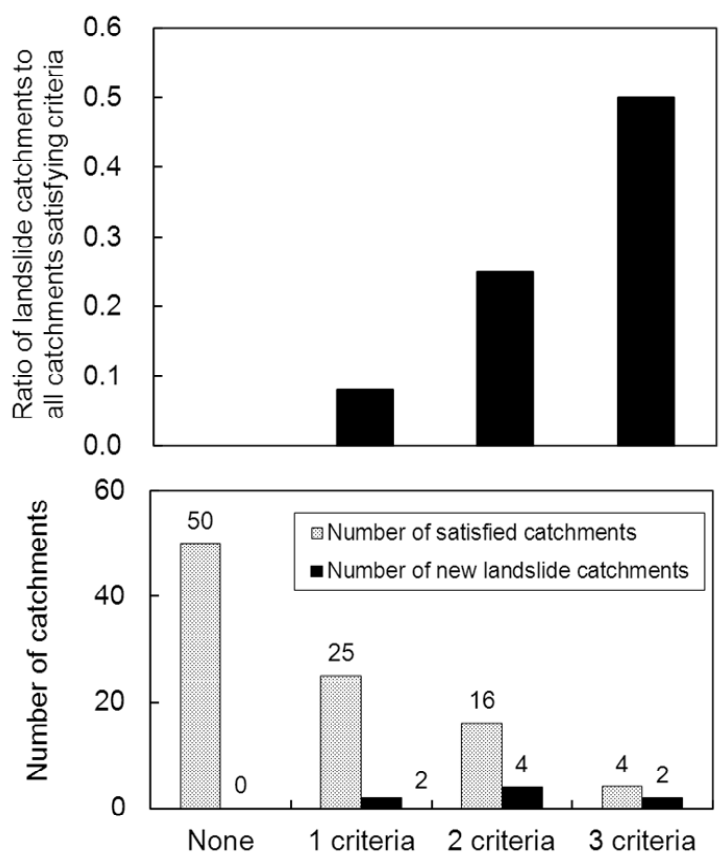

Fig. 9 Total catchments and new landslide catchments satisfying different numbers of susceptibility criteria (lower panel) and their ratios (upper panel)

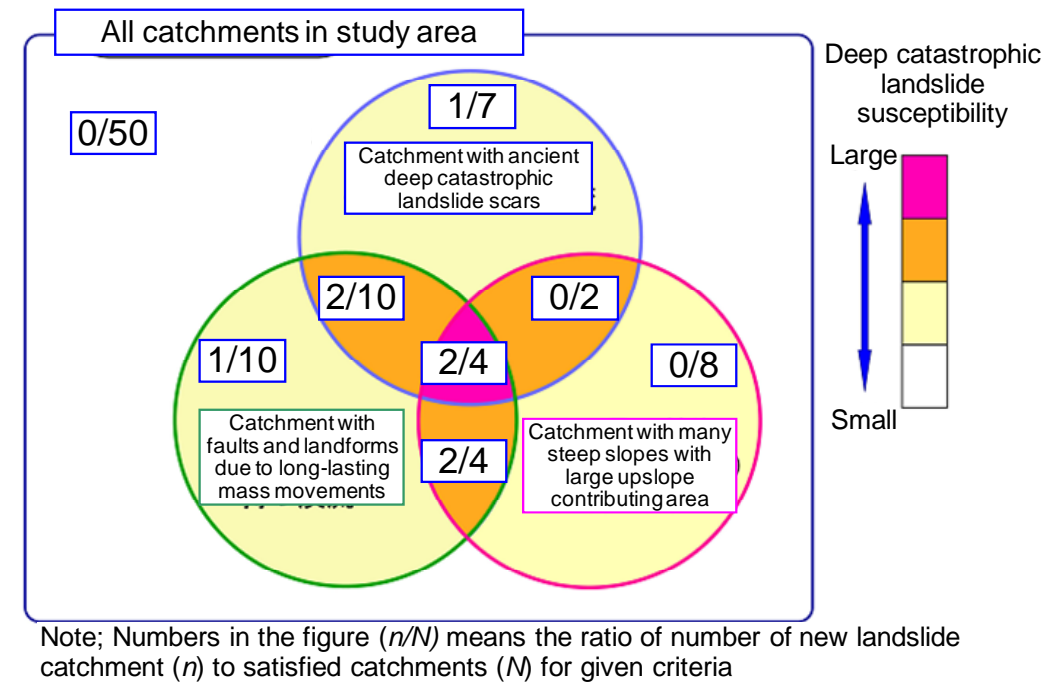

Fig. 10 Numbers of catchments with new landslides and catchments satisfying the given criteria 
with many steep slopes with large upslope contributing areas. We confirmed the applicability of this method in a study area around Mount Wanitsuka, Japan.

\section{REFERENCES}

Agliardi, F., Crosta, G.B., Zanchi, A., and Ravazzi, C. (2009): Onset and timing of deep-seated gravitational slope deformations in the eastern Alps, Italy, Geomorphology, Vol. 103, pp. 113-129.

Brückl, E., and Parotidis, M. (2005): Prediction of slope instabilities due to deep-seated gravitational creep, Nat. Hazards Earth Syst. Sci., Vol. 5, pp. 155-172.

Chigira, M. (1992): Long-term gravitational deformation of rock by mass rock creep, Eng. Geol., Vol. 32, pp. 157-184.

Chigira, M. (2006): Prediction of potential landslide site from the viewpoint of geology and geomorphology, Journal of Geotechnical Engineering, Vol. 62, No. 4, pp. 722-735.

Chigira, M. (2009): September 2005 rain-induced catastrophic rockslides on slopes affected by deep-seated gravitational deformations, Kyushu, southern Japan, Eng. Geol., Vol. 108, pp. 1-15.

Chigira, M., and Kiho, K. (1994): Deep-seated rockslideavalanches preceded by mass rock creep of sedimentary rocks in the Akaishi Mountains, central Japan, Eng. Geol., Vol. 38, pp. 221-230.

Costa, J.E., and Schuster, R.L. (1988): The formation and failure of natural dams, Geol. Soc. Am. Bull., Vol. 100, pp. 1054-1068.

Crosta, G.B., and Agliardi, F. (2003): Failure forecast for large rock slides by surface displacement measurements, Can. Geotech. J., Vol. 40, pp. 176-191.

Crosta, G.B., Chen, H., and Frattini, P. (2006): Forecasting hazard scenarios and implications for the evaluation of countermeasure efficiency for large debris avalanches, Eng. Geol., Vol. 83, pp. 236-253.

Evans, S.G., Guthrie, R.H., Roberts, N.J., and Bishop, N.F. (2007): The disastrous 17 February 2006 rockslide-debris avalanche on Leyte Island, Philippines: a catastrophic landslide in tropical mountain terrain, Nat. Hazards Earth Syst. Sci., Vol. 7, pp. 89-101.

Guzzetti, F., Reichenbach, P., Cardinali, M., Galli, M., and Ardizzone, F. (2005): Probabilistic landslide hazard assessment at the basin scale, Geomorphology, Vol. 72, pp. 272-299.

Hatano, S. (1974): Topography caused by rapid mass movement (part II), Tsuchi to Kiso, Japanese Geotechnical Society, Vol. 22, No. 11, pp. 85-93.

Iwamatsu, A., and Shimokawa, E. (1986): Creep-type largescale landslides of well-cleaved Argillaceous rocks, the memories of the Geological Society of Japan, Vol. 28, pp. 67-76.

Jitousono, T., Shimokawa, E., and Teramoto, Y., (2008): Debris flow induced by deep-seated landslides at Minamata City, Kumamoto Prefecture, Japan in 2003, International Journal of Erosion Control Engineering, Vol. 1, pp. 5-10.

Kasai, M., Ikeda, M., Asahina, T., and Fujisawa, K. (2009): LiDAR-derived DEM evaluation of deep seated landslides in a steep and rocky region of Japan, Geomorphology, Vol. 113, pp. 57-69.

Korup, O., Clague, J.J., Hermanns, R.L., Hewitt, K., Strom, A.L., and Weidinger, J.T. (2007): Giant landslides, topography, and erosion, Earth Planet. Sci. Lett., Vol. 261, pp. 578-589.

Korup, O., and Schlunegger, F. (2007): Bedrock landsliding, river incision, and transience of geomorphic hillslopechannel coupling: Evidence from inner gorges in the Swiss Alps, J. Geophys. Res., Vol. 112, F03027, doi:10.1029/2006JF000710.

Machida, H. (1967): A consideration of scale and recurrence relation of a landslide in a devastated mountain area, Water Science, Vol. 11, No. 2, pp. 30-53.

McKean, J.A., and Roering, J.J. (2004): Landslide detection and surface morphology mapping with airborne laser altimetry, Geomorphology, Vol. 57, pp. 331-351.

Mokudai, K., and Chigira, M. (2004): Geomorphic features and processes of gravitational mountain deformation in the area from Mt. Yambushi to Oya-Kuzure, Central Japan, Geographical Review of Japan, Vol. 77, No. 2, pp. 55-76.

Montgomery, D.R. (2001): Slope distributions, threshold hillslopes and steady-state topography, Am. J. Sci., Vol. 301, pp. 432-454.

Montgomery, D.R., and Dietrich, W.E. (1994): A physically based model for the topographic control on shallow landsliding, Water Resour. Res., Vol. 30, pp. 1153-1171.

Nakagawa, A., and Okunishi, K. (1977): A large-scale landslide at Shigeto, Kochi Prefecture, Part 1: Characteristics of ground structure on the landslide, Disaster Prevention Research Institute Annuals, Vol. 20, No. B-1, pp. 209-222.

Nishii R., and Matsuoka, N. (2010): Monitoring rapid head scarp movement in an alpine rockslide, Eng. Geol., Vol. 115, pp. 49-57.

O'Callaghan, J.F., and Mark, D.M. (1984): The extraction of drainage networks from digital elevation data, Comput. Vision Graphics Image Process., Vol. 28, pp. 328-344.

Roering, J.J., Kirchner, J.W., and Dietrich, W.E. (2005): Characterizing structural and lithologic controls on deepseated landsliding: Implications for topographic relief and landscape evolution in the Oregon Coast Range, USA, Geol. Soc. Am. Bull., Vol. 117, pp. 654-668.

Roering, J.J., Stimely, L.L., Mackey, B.H., and Schmidt, D.A. (2009): Using DInSAR, airborne LiDAR, and archival air photos to quantify landsliding and sediment transport, Geophy. Res. Lett., Vol. 36, L19402, doi:10.1029/2009GL040374.

Shieh, C-L., Wang, C-M., Lai, W-C., Tsang, Y-C., and Lee, SP. (2009): The composite hazard resulted from Typhoon Morakot in Taiwan, Journal of the Japan Society of Erosion Control Engineering, Vol. 62, No. 4, pp. 61-65.

Shimokawa, E., and Iwamatsu, A. (1986): Creep induced landslide in Kyushu Mountains, Proceeding for Annual Meeting of Japan Society of Erosion Control Engineering, pp. 194-197.

Suzuki, R., Kurihara, J., Sakurai, W., and Sakai, N. (2007): Characteristics and an extraction method of deep landslide prone area occurred by heavy rainfall, Civil Engineering Journal, Vol. 49, No. 5, pp. 58-63.

Suzuki, R., Uchida, T., and Tamura, K. (2009): Execution of a survey on ground structure for identifying areas prone to deep-seated landslide, Civil Engineering Journal, Vol. 51, No. 7, pp. 8-13.

Takaya, S., and Suzuki, K. (2007): Huge mountain failure caused by Typhoon No. 14 in Miyazaki Prefecture in 2005, Journal of the Japan Landslide Society, Vol. 44, No. 2, pp. 20-26.

Tamura, K., Uchida, T., Suzuki, T., Terada, H., and Kurihara, J. (2008): Manual on the method for extraction of torrents prone to a massive landslide occurrence, Public Work Research Institute Data No. 4115.

Taniguchi, Y. (2008): Sediment disasters caused by typhoon No. 14, 2005, in Miyazaki Prefecture, International Journal 
of Erosion Control Engineering, Vol. 1, pp. 11-19.

Terado, T. (1986): The distribution of landforms caused by large-scale mass movement on Shikoku island and their regional characteristics, Memoirs of the Geological Society of Japan, Vol. 28, pp. 221-232.

Teramoto, K., Asai, W., and Nagasawa, R. (1987): Analysis of topography and geology the slopes where large scale landslide occurred; a case study of Kankikuzure and Kaerikumoyamakuzure, Proceeding for Annual Meeting of Japan Society of Erosion Control Engineering, pp. 18-21.

Uchida, T., Osanai, N., Onoda, S., Takayama, T., and Tomura, K. (2006): A simple method for producing probabilistic seismic shallow landslide hazard maps, Proceedings of Interpraevent 2006, pp. 529-534.

Uchida, T., Suzuki, R., and Tamura K. (2007): Evaluation of deep-seated slope failure susceptibility using geology and rock uplift rate database, Civil Engineering Journal, Vol. 49, No. 9, pp. 32-37.

Uchida, T., Miyata, S., and Asano, Y. (2008): Effects of the lateral and vertical expansion of the water flowpath in bedrock on temporal changes in hillslope discharge, Geophys. Res. Lett., 35, L15402,
doi:10.1029/2008GL034566.

Uchida, T., Matsuoka, A., Matsumoto, N., Matsuda, J., Akiyama, K., Tamura, K., and Ichinohe, K. (2009): Overtopping erosion of landslide dam at Numakuraurasawa, San-hazama river Miyagi Prefecture, Japan, Journal of the Japan Society of Erosion Control Engineering, Vol. 62, No. 3, pp. 23-29.

Uchida, T., Nakano, Y., Akiyama, K., Tamura, K., Kasai, M., and Suzuki, R. (2010): The role of LiDAR data on evaluation of shallow landslide susceptibility and detection of mass rock creep, Trans. Jpn. Geomorph. Un., Vol. 31, pp. 385-401.

Wang W-N., Furuya T., and Chigira, M. (2003): Geological and geomorphological precursors of the Chiu-fen-erh-shan Landslide triggered by the Chi-chi Earthquake in Central Taiwan, Eng. Geol., Vol. 69, pp. 1-13.

Yokoyama, O., Uchida, T., Tamura, K., Suzuki, R., and Inoue, T. (2011): Relationship between catastrophic landslide and geomorphological and geological features in Mt. Wanitsuka, Miyazaki Prefecture, Journal of the Japan Society of Erosion Control Engineering, Vol. 63, No. 5, pp. 3-13. 